\title{
Student's attitudes relating to web mediated problem based learning
}

\author{
Mustafa Serkan GÜNBATAR* \\ Hayati ÇAVUŞ **
}

\begin{abstract}
Aim of this study is to designate the students' attitudes at the end of the web mediated problem-based learning process. In research, one sample post-test experimental design was used. The study group consists of 30 students, educating in 2007-2008 education year spring semester and enrolled in the Primary Education department of Faculty of Education, Yüzüncü Yıl University. During the period of seven weeks, course committed to work group by Web Mediated Problem Based Learning. After the experimental process, Web Mediated Problem Based Learning Attitude Scale was applied to the students and necessary data was obtained. Students' general attitudes about the process of Web Mediated Problem Based Learning proved positively high.
\end{abstract}

Keywords: Attitude, problem based learning, web based instruction.

* Res. Assist., Yüzüncü Yıl University, Education Faculty, Department of Computer Education and Instructional Technology, Van, Turkey. E-mail: mustafaserkan@yyu.edu.tr ** Assist. Prof. Dr., Yüzüncü Y1l University, Education Faculty, Department of Computer Education and Instructional Technology, Van, Turkey. E-mail: hcavus@yyu.edu.tr 


\section{SUMMARY}

Purpose and Significance: The aim of this study is to determine the students' attitudes after a web mediated problem-based learning process. Researches about problem based learning, integration with technology and its effects on students in Turkey are not qualified.

Methods: This research has been carried out by a group of preexperimental design model. The explanatory variable is practiced learning strategy (Web Mediated Problem Based Learning). The response variable is students' attitudes. The research was applied to 30 students of Department of Primary Education Student Teachers who were attending the Computer II lesson in 2007-2008 spring term in Education Faculty of Yüzüncü Yıl University. Students were divided into six work groups including five members each. In this research a web based software, designed by researcher, was used. After designing the web based environment, two doctoral researches about web mediated problem based learning, were examined and researchers' suggestions were taken into consideration. An attitude scale, developed by Alper (2003) with the aim of measuring students' attitudes about web mediated problem based learning and lesson of Computer II, subject of "Data Presentation", was used. As a result of the interviews with scale developer, it was concluded that it would be better to use all items of the original scale and to adapt the scale to the mentioned research. Therefore total of 172 students has been educated with Web Mediated Problem Based Learning Approach. At the end of the seven week problem based learning period, relevant scale was applied to students and required analyses were made by collected data.

The scale was assessed by using factor analysis method. The scale which had originally included 52 items, was decreased to 39 items and observed five sub-dimensions. Factors of scale are parallel to the original form of "Relating To Computer Lesson Items", "Relating To Collaborative Learning", "Web Based Learning", "By Oneself Learning" and "Problem Solving". The reliability coefficients of sub-dimensions of the scales are in the range of 0,85 to 0,65 . The total reliability coefficient of the scale is 0,90 .

Results: At the end of the period, the mean score of the attitudes related to Web Mediated Problem Based Learning is $\overline{\mathrm{X}}=4,07$. This value can be considered as a high level attitude. The mean score of students' attitudes related to Computer lesson is $\overline{\mathrm{X}}=4,25$. The mean score of students' attitudes 
related to collaborative learning is $\overline{\mathrm{X}}=3,99$. The mean score of students' attitudes related to web mediated learning is $\overline{\mathrm{X}}=4,09$. The mean score of students' attitudes related to self- learning is $\bar{X}=3,99$. The mean score of students' attitudes related to problem solving is $\bar{X}=4,00$. To assess the scale's total score, a speculation was gained through the value 0,66 resulted by dividing the difference $(5-1=4)$ between maximum and minimum possible scores into 6. According to the criteria the 1,00-1,66 range is too low attitude level. The 1,67-2,33 range is low attitude level. The 2,34-3,66 range is middle attitude level. The 3,67-4,33 range is high attitude level and the 4,34-5,00 range is too high attitude level. With this interpretation criteria, regarding to web mediated problem based learning, students' attitudes are in high level positive.

Discussion and Conclusions: According to the findings, researchers made some suggestions. As a result of the students' high level attitudes about Web Mediated Problem Based Learning, using this strategy in appropriate lessons is suggested. In the future, studies that are in-group communication improver and relevant to problem based learning concerning different levels (primary, secondary etc.) are recommended to be performed. 


\title{
Web Tabanlı Probleme Dayalı Öğrenmeye İlişkin Öğrenci Tutumları*
}

\author{
Mustafa Serkan GÜNBATAR ${ }^{* *}$ \\ Hayati ÇAVUŞ ${ }^{* * *}$
}

ÖZ. Bu çalışmanın amacı, web tabanlı gerçekleştirilen Probleme Dayalı Öğrenme süreci sonunda öğrenci tutumlarını belirlemektir. Araştırmada tek grup sontest deneysel desen kullanılmıştır. Çalışma grubu, 2007-2008 öğretim yılı bahar yarıyılında, Yüzüncü Yıl Üniversitesi Eğitim Fakültesi İlköğretim Bölümü'nde öğrenim gören 30 birinci sınıf öğrencisinden oluşmaktadır. Çalışma grubu öğrencilerine 7 hafta boyunca Web Tabanlı Probleme Dayalı Öğrenme yaklaşımı ile ders işlenmiş̧ir. Deneysel işlem sonunda Web Tabanlı Probleme Dayalı Öğrenme Tutum Ölçeği uygulanarak gerekli veriler elde edilmiștir. Öğrencilerin Web Tabanlı Probleme Dayalı Öğrenme sürecine ilişkin genel tutumları olumlu yönde yüksek çıkmıştır.

Anahtar Sözcükler: Probleme dayalı öğrenme, tutum, web tabanlı eğitim.

\footnotetext{
* Bu çalışma Mustafa Serkan Günbatar adlı araştırmacının Yüksek Lisans tezinin bir bölümünden faydalanılarak düzenlenmiştir.

** Arş. Gör., Yüzüncü Y1l Üniversitesi, Eğitim Fakültesi, Bilgisayar ve Öğretim Teknolojileri Eğitimi Bölümü, Van, Türkiye. E-posta: mustafaserkan@yyu.edu.tr

Yrd. Doç. Dr., Yüzüncü Yıl Üniversitesi, Eğitim Fakültesi, Bilgisayar ve Öğretim Teknolojileri Eğitimi Bölümü, Van, Türkiye. E-posta: hcavus@yyu.edu.tr
} 


\section{GİRIŞ}

Çağdaş eğitim ortamlarında öğrenenin merkezde olduğu, aktif olarak araştırdığı, sorguladığı ve gerekli bilgiyi bireysel özelliklerine göre yapılandırdığı uygulamaları sıklıkla görmekteyiz. Bu uygulamaları kapsayan yaklaşım, 1970'li yıllardan itibaren Eğitim Teknolojisi disiplininin üzerinde durduğu, bilginin bireyin deneyimleri bağlamında içsel olarak yapılandırıldığını vurgulayan ve ögrenme kavramı ile ilgilenen bir yaklaşımdır (Deryakulu, 1995). Yabancı alanyazın incelendiğinde İngilizce olarak Constructivism şeklinde ifade edilen bu yaklaşım dilimizde yaygın olarak Yapılandırmacılık şeklinde ifade edilmektedir ve Yapılandırmacılık teriminin kullanılması önerilmektedir (Şimşek, 2004).

Yapılandırmacılığın üzerinde durduğu nokta bilginin bireyden bağımsız şekilde bulunması durumundan çok bilgiye anlamın bireyler tarafından yüklenmesi durumudur (Duffy and Jonassen, 1992). Probleme Dayalı Öğrenme (PDÖ); öğrenciyi gerçek yaşamda karşılaşabileceği iyi yapılandırılmamış bir problemle karşı karşıya getirerek, gereksinim duyabileceği kaynakları ve rehberliği sağlayarak, öğrencinin derinlemesine düşünmesini, böylece konuyu problem çözme süreci içinde kendi kendine öğrenmesini ayrıca problem çözme becerilerini de kazanmasını sağlamayı hedefleyen bir yaklaşımdır (Barrows, 1985). PDÖ, sadece problem çözmek değildir; problemleri çözme aşamasında öğrencilerin üst düzey zihinsel becerilerini kullanarak bilgiyi ve anlamı zenginleştirmeleridir (Wood, 2003). PDÖ belirli bir disiplindeki kavramlara yönelik olarak problem durumları organize edildiğinden ve süreç tümdengelim yoluyla ilerlediğinden yapılandırmacılıkla örtüşmektedir (Yurdakul, 2005). PDÖ’de öğretmen bilgiyi vermekten ziyade öğrenme işlemine rehberlik eder, aktif olarak dinler, kritik düşünmeyi cesaretlendirir, öğrencilerin muhakeme işlemlerini sorgular ve geri bildirim sağlar. Öğrenciler, hem öğrenmeye hem de ögretmeye aktif olarak katılırlar. Öğrenciler öğrenme durumlarını bağımsız olarak araştırmaktan, bilgi organizasyonundan ve diğer öğrencilere bilgi öğretmekten, kavramlardan, öğrenme durumlarıyla ilgili prosedürlerden sorumludurlar (Catney \& Currie, 1999). PDÖ sürecinde öğrenme hem küçük gruplarda yüz yüze hem de bireysel çalışma yoluyla olmaktadır (Stromso, Grottumpt ve Lycke, 2007). PDÖ' de grup çalışması genellikle aynı problemi çözmek amacı ile bir araya gelen, ideal olarak beş-yedi üyeden oluşan öğrenenler topluluğu ile gerçekleşmektedir (Heinrics, 2002) ve grup çalışması önemli bir yere sahiptir. Eğitimcilerin işbirlikli öğrenme stratejilerinin eğitimsel çıtıları arttırdığı konusundaki hemfikir olma durumları (Ifamuyiwa ve Akinsola, 2008) da grup çalışmasının önemini destekler niteliktedir. 
Grup çalışması ve insanlar arası iletişimin önemli olduğu PDÖ gibi öğrenme ortamlarında öğrencilerin bu sürece ilişkin olumlu tutumlarının öğrenci performansını dolayısıyla da grup performansını arttıracağı açıktır. Ifamuyiwa ve Akinsola (2008), bireyin tutumunun ilgili durumla ilgili performansına ve davranışına etkisinin göz önünde bulundurulabileceğini ifade etmektedirler. $\mathrm{Bu}$ noktadan hareketle tutum kavramından ne anlaşılması gerektiğinin netleştirilmesi ve bunun ölçümünün nasıl olabileceğinin ortaya konması önemlidir.

Sosyal bilimlerdeki pek çok kavram gibi tutum kavramının ne olduğu ile ilgili tam bir görüş birliği oluşmamıştır. Bunun sonucu olarak yapılan tutum tanımlarından her biri tutumun ne olduğuna ilişkin az da olsa farklı bir kavramsallaştırma içermekte ya da tutumun farklı bir yönünü vurgulamaktadır (Tavşancıl, 2002). Tutumla ilgili tanımlar incelendiğinde çoğunun "bir uyaranla karşılaşıldığında, net bir biçimde harekete geçme veya harekete geçme eğiliminde olmaya hazırlık durumudur" şeklindeki bir ifadeyi kabul ettikleri görülür (Oppenheim, 1966, s105).

Bir eğilimin tutum olarak değerlendirilebilmesi için asgari şart zihinsel değerlendirmedir. Kişilerin yerleşik tutumlarının çoğu duyuşsal ve davranışsal öğeleri de içermektedir (Tavşancıl, 2002). Bir duruma karşı bireylerin olumlu tutum geliştirmeleri davranışlarına da yansıyacak, ilgili durumla ilgili faaliyetlerin gerçekleşmesine olumlu yaklaşacaklardır (Helvacı, 2008). Bu ifadeden de anlaşıldığı üzere bireylerin bir objeye ilişkin tutumları netleştikçe duyuşsal olarak anlam kazanmakta ve davranışsal olarak da gözlenebilmektedir. Bunun paralelinde yeni bir yaklaşıma göre düzenlenen öğrenme ortamlarına ilişkin öğrenci tutumları, ortamın başarısı için belirleyici bir etkiye sahiptir.

Alan yazın incelendiğinde, tutumları bilişsel, duyuşsal ve davranışsal eğilimlerin bütünleşmesiyle açıklayan bir modelin kabul gördüğü anlaş1lmaktadır (Oppenheim, 1966; Tavşanc11, 2002; Tekindal, 2002; Köklü, 1995). Bu modele üç öğeli tutum modeli adı verilmiştir. Tutumların bilişsel öğeleri tutum objeleri (uyarıcıları) ile ilgili bireyin elde etmiş olduğu bilgileri temsil etmektedir. Tutumun duyuşsal öğesi, bireyden bireye değişiklik gösteren, bireyin değer sistemiyle yakından ilgili olan, gerçeklerle açıklanamayan hoşlanma-hoşlanmama şeklinde ifade edilebilen yönüdür. Tutumun davranışsal öğesi yerleşmiş güçlü tutumları temsil eden bireylerin tutum objesine karşı beslediği duygular, tutum objesine ilişkin bilgi ve düşünceleri sonucunda gerçekleştirdiği hareketleri temsil etmektedir (Tavşancıl, 2002). Ayrıca tutumların ölçümü için de üç ayrı yaklaşım söz konusudur. Bunlar; Bir grup sıfat yada tutum cümlesine verilen cevaplardan çıkarsamalar (ölçekler), Davranışlardan yapılan çıkarsamalar ve Fizyolojik tepkilerden yapılan çıkarsamalar şeklinde ifade edilebilir (Çıkrıkçı, 1991). 
Uygulanmalarının kolay olması, objektif olarak değerlendirilebilmesi ve güvenirlik özelliklerinden dolayı ölçekler tutum araştırmalarında sıklıkla kullanılmaktadırlar. Bu çalışmada da tutum ölçmek için daha önceden benzer bir araştırma kapsamında, Web Tabanlı Probleme Dayalı Öğrenme (WTPDÖ) ye ilişkin öğrenci tutumlarını belirlemek amacıyla geliştirilmiş olan bir tutum ölçeği, çalışmaya uyarlanarak kullanılmıştır.

PDÖ'nin web tabanlı uygulamaları, son yıllarda sıklıkla üzerinde durulan çalışmalardır. Yüksekögretimde bilgisayar, bilgi teknolojileri ve world wide web (www) kullanımı yaygınlaşmaktadır. Böylelikle, WTPDÖ için alt yapının giderek daha iyi duruma geldiği düşünülebilir. Bununla birlikte, Amerika Birleşik Devletlerinde bulunan, Web Tabanlı Eğitim Komisyonu ve Yüksek Öğretim Politikası Kurumu, gelecekteki araştırmaların teorik çerçeveye dayandırılmasını, araştırmaların öğretmen ve içerik merkezli durumdan çıkarak, öğrenci merkezli olmasını önermektedirler (Yang, 2001). Bu ifadeden de anlaşılacağı üzere, web tabanlı verilecek bir takım eğitimlerin öğrenci merkezli olması gereği, bilimsel çevrelerce açık bir şekilde ifade edilmektedir.

PDÖ gibi öğrenen merkezli uygulamaların web tabanlı olarak gerçekleştirilmesi, öğrencilerin sürece ilişkin tutumlarının grup performansını ve öğrenmeyi arttırması beklentisinden hareketle tutumlarının tespit edilmesi önemli görülmektedir.

\section{Araştırmanın Amacı}

Yapılan bu çalışmada, WTPDÖ yöntemiyle uzun zaman diliminde (7 hafta) işlenen ders sonrasında bu yönteme ilişkin öğrenci tutumlarının ne düzeyde olduğu belirlenmeye çalış1lmıştır.

\section{YÖNTEM}

\section{Araştırma Modeli}

Araştırmada yarı deneysel modeller içerisinde yer alan tek grup sontest model kullanılmıştır. Buradaki yordayıcı değişken, uygulanan öğrenme stratejisi (Web Tabanlı Probleme Dayalı Öğrenme), yordanan değişken ise öğrenci tutumlarıdır.

\section{Çalışma Grubu}

$\mathrm{Bu}$ araştırma, 2007-2008 öğretim yılı bahar yarıyılında Yüzüncü Yıl Üniversitesi Eğitim Fakültesi ilköğretim bölümünde öğrenim gören, aynı öğretim yılının güz döneminde Bilgisayar-I dersini başarıyla tamamlamış 
olan, Bilgisayar II dersini almakta olan toplam 30 birinci sınıf öğrencisi ile yürütülmüştür. Öğrenciler beşer kişilik altı çalışma grubuna ayrılmış ve geliştirilen web tabanlı öğrenme materyali aracılığıyla grup çalışması yapmaları sağlanmıştır. Yedi haftalık uygulamadan önce, öğrencilere PDÖ ve PDÖ sürecinde nasıl öğrenecekleri ile ilgili bilgi verilmiş ve ön uygulama yaptırılmıştır. Ön uygulamanın hemen ardından asıl uygulama gerçekleştirilmiştir.

Yedi haftalık uygulamanın birinci haftasında, her öğrenciye üzerinde dersin yürütüleceği web sayfasının adresi, sayfaya giriş için oluşturulan kullanıcı adı, şifresi, grubu, daha önceden oluşturulan ogr.yyu.edu.tr (xxxxx@ogr.yyu.edu.tr gibi) uzantılı mail adresi ve şifresinin yazılı bulunduğu kağıtlar dağıtılmıştır. Her gruptan bir öğrenciye öğrencinin de gönüllü olması kaydıyla yazıcı sorumluluğu verilmiştir. Yazıcı öğrenciler diğer öğrencilerden farklı olarak, problem durumunu açıklığa kavuşturmak için çevrimiçi ortamda grup üyeleri arasında yapılan tartışmalar sonucunda belirlenen "Bildiklerimiz", "Bilmediklerimiz", "Problem İfademiz" ve "Yapacaklarımız" başlıkları altında toplanan sayfalara veri girişi yapabilmişler ve bu alanları güncelleyebilmişlerdir. Öğrenciler bu hafta WTPDÖ için hazırlanan web sayfasını da incelemişler, takıldıkları yerlerde araştırmacıdan yardım almışlar ve öğrenme materyalini tanımaya çalışmışlardır. Ayrıca, öğrencilere öğrenme materyali üzerinden aşağıda belirtilen iyi yapılandırılmamış problem durumu da sunulmuştur.

Milli Ĕ̈itim Bakanlı̆̆ (MEB) ögrretmen atamalarında KPSS sınav sistemini kaldırma kararı almış bulunmaktadır. Fakat Maliye Bakanlığı'nın verdiği kadrolar sinırlı olduğundan ögretmen adaylarının elemeden geçirilmesi gerekmektedir. $M E B$, ögretmen adaylarının atanmasında yapacağı elemeyi birinci sinifin ikinci döneminden itibaren dört yll boyunca ögretmen adaylarına staj yaptırarak ve bu staj sonuçlarını değerlendirerek yapmaya başlayacaktır. Bu uygulamanin yapılacă̆ ilk öğretmen adayları da sizlersiniz.

Danışman öğretim üyesi sizleri gruplara ayırarak staj yapacağınız okullara gönderir. Gittiğiniz okuldaki müdür ve diğer öğretim kadrosu stajın sizin için ne kadar önemli olduğunu ve MEB' in staj sonucuna ne kadar önem verdiğinin farkindadır ve sizlerle bir toplant yaparlar. Bu toplantıda $M E B$ ' in ögretim teknolojilerine verdiği önem ve yaptı̆̆ yatırımlara değinilir. Bu doğrultuda okul idaresi ögretmen adayları olarak sizlerin biliş̧im teknolojilerini eğitim ortamında 
kullanabilme yeterliliğinizi görmek istemektedir. Bunun için sizden bir buçuk ay içinde grup çalışması yaparak, ders esnasında öğrencilere konu anlatırken sunabileceğiniz, ilköğretim düzeyinde herhangi bir konuyu ögretim yazılımı şeklinde hazırlamanız istenmektedir. Bir buçuk ay sonra yaptığınız projeyi danışman ögretim üyesinin ve okul idaresinin bulunduğu bir ortamda sunmanız da istenmektedir. Yaptığınız bu proje ve sunum staj değerlendirmenizde önemli bir yere sahip olacaktır.

İkinci hafta, çalışma grubu öğrencileri Eşzamanlı Görüşme modülü aracılığı ile web ortamında tartışmışlar, bildiklerini ve bilmediklerini belirleyip problem durumunu açıklığa kavuşturmaya çalışmışlardır. Yazıcı görevini üstlenen öğrenciler bilinenler ve bilinmeyenleri sadece yazıcılara verilen hakları kullanarak sayfada ilgili alanlara eklemişlerdir.

Üçüncü hafta, öğrenciler grup içi görüşmelerle problem durumunu açıklığa kavuşturmaya çalışmışlardır. Yazıcı olarak görevlendirilen öğrenciler bilinenler ve bilinmeyenleri sayfaya eklemişler ve düzenlemişlerdir. Ayrica bu hafta öğrencilerin problem durumunu netleştirmelerine ve kabataslak olarak yapacaklarını yazmalarına yardımcı olacak bazı sorular web üzerinden sunulmuştur.

Dördüncü hafta, çalışma grubu öğrencileri bildikleri, bilmedikleri, problem ifadesi ve yapacaklarını netleştirip uygulamaya başlamışlardır. Öğrencilere ayrıca, problem durumunu olgunlaştırmalarına yol gösterici olacağı düşünülen bazı sorular web üzerinden sunulmuştur.

Beşinci haftada, öğrencilere "Web Tabanlı Probleme Dayalı Öğrenme' nin sizce olumlu ve olumsuz yanları nedir?" sorusu yöneltilerek yazılı olarak bu konudaki fikirleri alınmıştır. Ayrıca bu hafta da öğrenciler grup çalışmasına devam etmişlerdir.

Altıncı haftada, tüm gruplardaki öğrenciler olgunlaştırdıkları problem durumunu çözmek için "Yapacaklarımız" başlığı altında belirledikleri faaliyetleri gerçekleştirmeye başlamışlar, belirledikleri konu ile ilgili sununun içeriği ve görsel öğelerinin oluşturulması üzerinde yoğunlaşmışlardır. Öğrenciler bu hafta daha ağırlıklı olarak web sayfasının kaynaklar bölümü altındaki "Uzmana danış", "Web'de arama" ve "Önerdiğimiz kaynaklar" sayfaları üzerinde yoğunlaşmışlardır.

Yedinci haftada öğrenciler grup projelerini hazırlamaya devam etmişler ve tamamlamaya çalışmışlardır. Öğrenciler grup projelerini internetten taradıkları resimler, hareketli resimler, animasyonlar ve müziklerle zenginleştirmişlerdir. Ders esnasında tüm öğrenciler öğretim üyesinden yardım almışlar, internetten tarama yapmışlar ve kitaplardan 
faydalanmışlardır. Öğrenciler ayrıca Web sayfasındaki "Kaynaklar" bölümünden faydalanabilmişler ve faydalı gördükleri sayfaları önerilen kaynaklar bölümünden yayınlanması için öğretim üyesine göndermişlerdir. Yedinci haftanın sonunda WTPDÖ uygulaması bitmiş, bundan sonraki hafta öğrencilere WTPDÖ tutum ölçeği uygulanmış ve gerçekleştirdikleri grup projelerini sunmaları istenmiştir.

\section{Öğrenme Materyali}

$\mathrm{Bu}$ araştırmada, çalışma grubu öğrencilerinin PDÖ etkinliklerini gerçekleştirebilmeleri için daha önceden WTPDÖ ile ilgili doktora çalışması yürütmüş olan Alper (2003) ve Özdemir (2005)' in çalışmaları incelenmiş, yapılan birebir görüşmeler sonrasında getirilen öneriler de göz önünde bulundurularak, araştırmacı tarafından web tabanlı olarak bir yazılım geliştirilmiş ve geliştirilen bu yazılım kullanılmıştır. Araştırmacı tarafından geliştirilen yazılım uygulamasına http://pdo.yyu.edu.tr adresinden erişen öğrenciler kendilerine verilen kullanıcı adı ve şifrelerini girerek, grup numaralarını seçerek ilgili sayfalara ulaşabilmişlerdir (bakınız şekil 1). Öğrenme materyali her grubun eşzamanlı ve eşzamansız görüşmeleri sonucu kendi kararlarıyla düzenledikleri "Bildiklerimiz", "Bilmediklerimiz", "Problem İfademiz" ve "Yapacaklarımız" başlıkları altında toplanan sayfalardan ibaret birinci bölüm (bakınız şekil 2); yine her grubun kendi içinde görüşme yapabildiği "Mesaj Panosu" ve "Eşzamanlı Görüşme" alanlarından oluşan Görüşme bölümü (bakınız şekil 3); tüm grupların ulaşabildiği "Uzmana Danışma", "Web'de Arama" ve "Önerdiğimiz Kaynaklar" başlıkları altında toplanan Kaynaklar bölümü (bakınız şekil 4) olmak üzere üç ana bölümden oluşmaktadır. WTPDÖ uygulaması dahilinde, öğrencilerin zorunlu olarak aldıkları Bilgisayar-II dersi kapsamında "Veri Sunumu" konusunun öğretilmesi hedeflenmiştir. Çalışmada kullanılan öğrenme materyalinin örnek ekran görünümleri aşağıda sunulmuştur. 


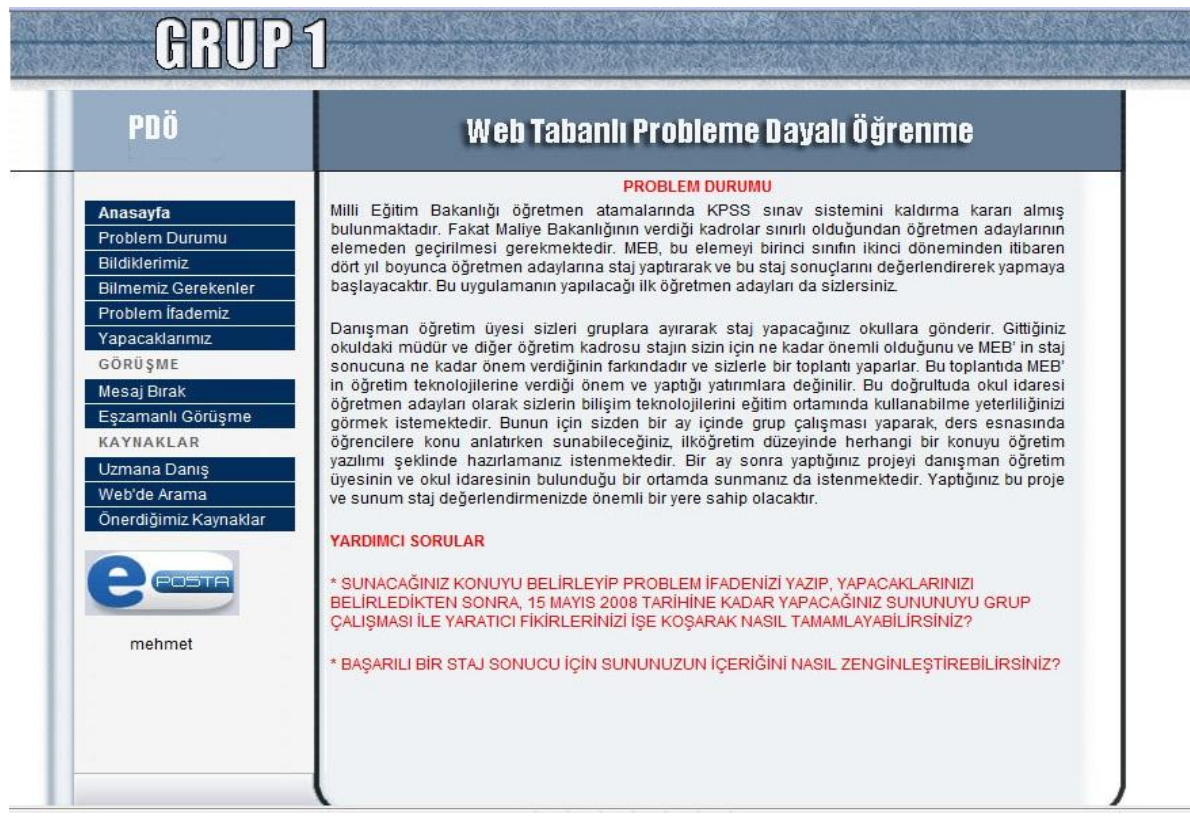

Şekil 1. Öğrenme materyali örnek ekran görünümü

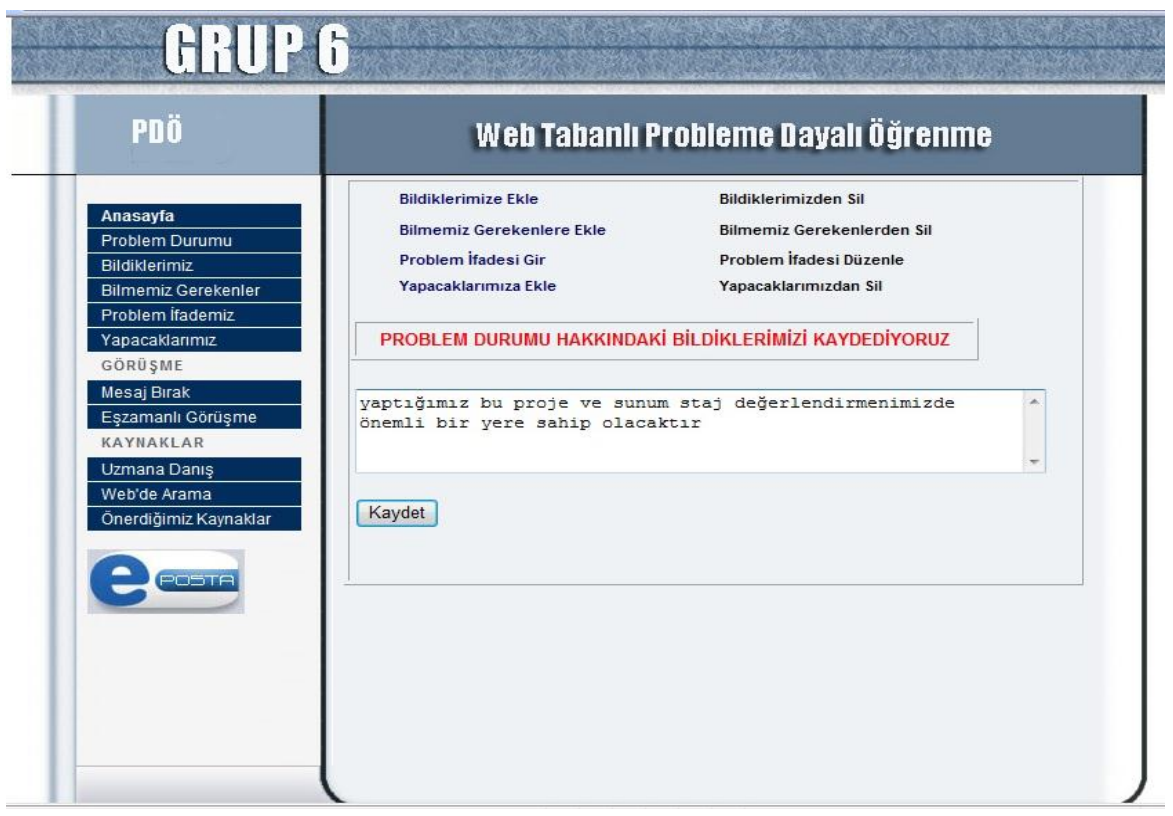

Şekil 2. Öğrenme materyalinin birinci bölümünden örnek ekran görünümü 


\section{..::Grup3 Eşzamanlı görüşme:...}

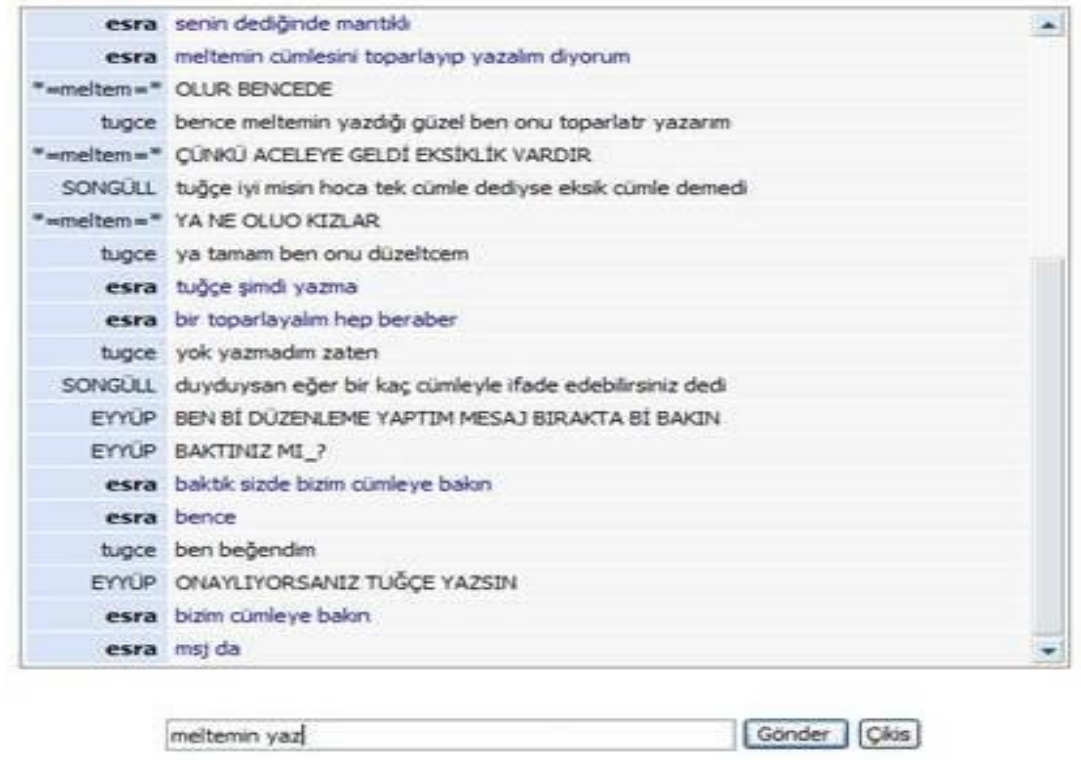

Şekil 3. Öğrenme materyalinin Görüşme bölümünden örnek ekran görünümü

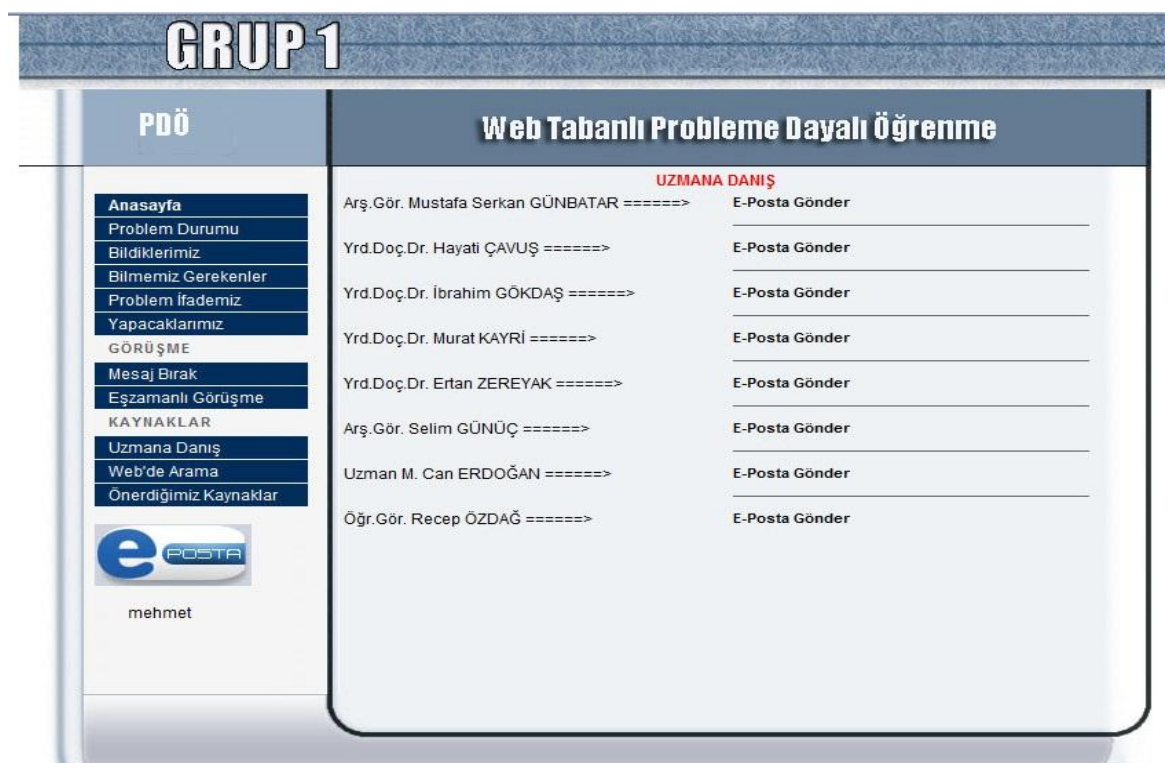

Şekil 4. Öğrenme materyalinin Kaynaklar bölümünden örnek ekran görünümü 


\section{Veri Toplama Aracı}

Araştırmada çalışma grubu öğrencilerinin WTPDÖ etkinliklerine ve uygulamanın gerçekleştirildiği Bilgisayar II dersi "Veri Sunumu" konusuna yönelik tutumlarını belirlemek amacıyla Alper (2003) tarafından geliştirilen tutum ölçeğinden yararlanılmıştır. Ayrıca uygulamanın beşinci haftasında öğrencilere “Web Tabanlı Probleme Dayalı Ögrenme' nin sizce olumlu ve olumsuz yanları nedir?" sorusu yöneltilerek yazılı olarak bu konudaki fikirleri alınmıştır.

Ölçeği geliştiren araştırmacıyla yapılan görüşme sonucu ölçeğin ilk halindeki tüm maddelerin kullanılarak bu çalışma için uyarlanmasının daha isabetli olacağı sonucuna varılmıştır. Bu doğrultuda gerekli analizlerin sağlıklı yapılabilmesi için mümkün olduğunca çok sayıda öğrencinin yetiştirilmesine karar verilmiştir. Yüzüncü Yıl Üniversitesi Eğitim Fakültesinde öğrenim gören ve çalışma grubuyla benzer özelliklere sahip, Bilgisayar II dersini alan toplam 142 öğrenciyle de çalışma grubu öğrencileriyle eşzamanlı olarak 7 hafta boyunca PDÖ stratejisi ile öğrenme faaliyetleri ayrıca yürütülmüştür. Süreç sonunda deney grubu (30 öğrenci) ile birlikte toplam 172 öğrenciye ölçek uygulanarak, elde edilen verilerle gerekli analizler yapılmıştır.

Ölçeğe Faktör analizi uygulanmış, verilerin faktör analizine uygunluğu Kaiser-Meyer-Olkin (KMO) testiyle test edilmiştir. "KMO değerinin 0,60 ve üzerinde olması, ölçekler için faktör analizi uygulanabileceğini göstermektedir" (Büyüköztürk, 2002) ifadesinden hareketle 0,780 olan KMO değerine bakarak ölçeğe faktör analizi uygulanabileceği sonucuna ulaşılmıştır. Uygulanan faktör analizi sonucu başlangıçta 52 maddeden oluşan ölçeğin 39 maddeye indiği ve beş faktör altında incelenebildiği görülmüştür. Ölçek bu haliyle \%48,711 varyans açıklama yüzdesine sahiptir. $\mathrm{Bu}$ oran da sosyal bilimler çalışmalarında istenilen açıklama yüzdesi oranları içerisinde kabul edilebilirdir. Çizelge 1'de, ölçeğin uygulanmasının ardından elde edilen faktör yüklerinin dağılımı yer almaktadır.

Ölçek faktörleri orijinal ölçekle paralellik gösterecek şekilde "Bilgisayar dersine ilişkin maddeler", "İşbirliğine dayalı öğrenme", "Web’e dayalı öğrenme", "Kendi kendine öğrenme" ve "Problem çözme" olarak adlandırılmıştır. Ölçeğin birinci alt boyutu olan "Bilgisayar II dersine ilişkin maddeler" faktörünün güvenirlik katsayısı 0.85 ; ikinci alt boyutu olan "İşbirliğine dayalı öğrenme" faktörünün güvenirlik katsayısı 0.85 ; üçüncü alt boyutu olan "Web' e dayalı öğrenme" faktörünün güvenirlik katsayısı 0.81; dördüncü alt boyutu olan "Kendi kendine öğrenme" faktörünün güvenirlik katsayıs1 0.71; beşinci alt boyutu olan "Problem çözme" faktörünün 
güvenirlik katsayısı 0.65 olarak tespit edilmiş, ayrıca ölçeğin tamamının güvenirliğinin ise 0.90 gibi yüksek bir değere sahip olduğu görülmüştür.

Çizelge 1. WTPDÖ Tutum Ölçeğinin faktör yük dağılımları

\begin{tabular}{|c|c|c|c|c|c|c|}
\hline \multirow[t]{2}{*}{$\begin{array}{l}\text { Madde } \\
\text { No }\end{array}$} & & \multicolumn{5}{|c|}{ Faktör Yükleri } \\
\hline & & 1 & 2 & 3 & 4 & 5 \\
\hline 35 & $\begin{array}{l}\text { Veri sunumu konusunda verilen bilgiler günlük } \\
\text { yaşam için yararlıydı }\end{array}$ & 0,786 & & & & \\
\hline 34 & $\begin{array}{l}\text { Veri sunumu konusunda öğrendiğim bilgilerin çoğu } \\
\text { gelecekte kullanılabilecek türdendi }\end{array}$ & 0,723 & & & & \\
\hline 36 & $\begin{array}{l}\text { Veri sunumu konusunda öğrendiklerim önceden } \\
\text { bildiklerimi destekledi }\end{array}$ & 0,688 & & & & \\
\hline 37 & Veri sunumu konusunda yeni bilgiler edindim & 0,603 & & & & \\
\hline 39 & $\begin{array}{l}\text { Web ortamında Bilgisayar dersi çalışmak beni } \\
\text { güdüler. }\end{array}$ & 0,588 & & & & \\
\hline 38 & $\begin{array}{l}\text { Veri sunumu konusunda öğrendiklerim benim için } \\
\text { ilginçti }\end{array}$ & 0,533 & & & & \\
\hline 32 & $\begin{array}{l}\text { Problemlerin çözümünü araştırarak Bilgisayar dersi } \\
\text { konusunu çalışmaktan zevk alırım }\end{array}$ & 0,418 & & & & \\
\hline 33 & $\begin{array}{l}\text { Güncel bir sorunu araştırarak öğrendiğim Bilgisayar } \\
\text { dersi konularını uzun süre hatırlarım }\end{array}$ & 0,393 & & & & \\
\hline 16 & $\begin{array}{l}\text { Herkesin eşit katılım sağladığı grup çalışmalarını } \\
\text { tercih ederim }\end{array}$ & & 0,696 & & & \\
\hline 20 & $\begin{array}{l}\text { Grup çalışmasının zaman kaybı olduğunu } \\
\text { düşünmüyorum }\end{array}$ & & 0,680 & & & \\
\hline 17 & $\begin{array}{l}\text { Grup çalışmalarında çeşitli sorumluluklar almak } \\
\text { isterim }\end{array}$ & & 0,614 & & & \\
\hline 18 & $\begin{array}{l}\text { Çeşitli çözümleri olan bir problemi çözmek için } \\
\text { grupla çalışmak isterim }\end{array}$ & & 0,590 & & & \\
\hline 21 & $\begin{array}{l}\text { Grup çalışmasında çeşitli sorumluluklar almak beni } \\
\text { güdüler (motive eder) }\end{array}$ & & 0,588 & & & \\
\hline 14 & Grup içinde ortak çalışmaktan hoşlanırım & & 0,588 & & & \\
\hline 22 & $\begin{array}{l}\text { Problemi çözmek için grupla birlikte çalışmak } \\
\text { isterim }\end{array}$ & & 0,587 & & & \\
\hline 15 & Grupta arkadaşlarımla çalışmaktan memnunum & & 0,572 & & & \\
\hline 23 & $\begin{array}{l}\text { Gerçek yaşamla ilgili konuları çalışmak beni } \\
\text { güdüler (motive eder) }\end{array}$ & & 0,409 & & & \\
\hline 19 & $\begin{array}{l}\text { Grup içinde daha önceden konuyla ilgili bilgi sahibi } \\
\text { olan öğrenci arkadaşlarla problemi çözmek isterim }\end{array}$ & & 0,379 & & & \\
\hline 30 & $\begin{array}{l}\text { Sinıf dışında grup arkadaşlarımla web ortamındaki } \\
\text { iletişim araçlarıyla (e-mail, chat, discussion gibi) } \\
\text { iletişim kurabilirim }\end{array}$ & & & 0,739 & & \\
\hline 26 & $\begin{array}{l}\text { Web ortamındaki araçlarla (e-mail, chat, discussion } \\
\text { gibi) gerek sınıf içinde gerek sınıf dışında } \\
\text { arkadaşlarımla görüşmeyi isterim }\end{array}$ & & & 0,734 & & \\
\hline
\end{tabular}




\begin{tabular}{|c|c|c|c|c|c|c|}
\hline \multirow[t]{2}{*}{$\begin{array}{l}\text { Madde } \\
\text { No }\end{array}$} & & \multicolumn{5}{|c|}{ Faktör Yükleri } \\
\hline & & 1 & 2 & 3 & 4 & 5 \\
\hline 29 & $\begin{array}{l}\text { Web ortamında online yapılan sınavların } \\
\text { sonuçlarını anında öğrenmeyi tercih ederim }\end{array}$ & & & 0,729 & & \\
\hline 31 & $\begin{array}{l}\text { Bilgisayar dersindeki sorunları web ortamında } \\
\text { araştırarak çözmek isterim }\end{array}$ & & & 0,624 & & \\
\hline 27 & $\begin{array}{l}\text { Öğretmenimin e-mail gibi iletişim araçlarıyla web } \\
\text { ortamında anında geri bildirim (dönüt-feed back) } \\
\text { vermesi beni güdüler (motive eder) }\end{array}$ & & & 0,567 & & \\
\hline 24 & $\begin{array}{l}\text { Web ortamında arkadaşlarımla iletişim kurmaktan } \\
\text { zevk alırım }\end{array}$ & & & 0,562 & & \\
\hline 25 & $\begin{array}{l}\text { Web ortamında arama motorlarından bilgi } \\
\text { edinebilirim }\end{array}$ & & & 0,519 & & \\
\hline 28 & Web ortamında sınav olmayı isterim & & & 0,425 & & \\
\hline 2 & Hedeflere tek başıma ulaşabilirim & & & & 0,708 & \\
\hline 6 & $\begin{array}{l}\text { Yeni verilen bir konuyu kendi gayretimle } \\
\text { öğrenebilirim }\end{array}$ & & & & 0,667 & \\
\hline 5 & $\begin{array}{l}\text { Öğretmenin yardımı olmadan çeşitli öğretim } \\
\text { materyallerini ve ders notlarını çalışarak } \\
\text { öğrenebilirim. }\end{array}$ & & & & 0,588 & \\
\hline 1 & Zor problemleri çözebilirim & & & & 0,575 & \\
\hline 3 & $\begin{array}{l}\text { Güç bir problemle karşılaş̧ı̆̆ımda çeşitli çözümler } \\
\text { bulurum. }\end{array}$ & & & & 0,543 & \\
\hline 4 & $\begin{array}{l}\text { Karmaşık bir problemi çözmek için çaba } \\
\text { göstermekten zevk alırım. }\end{array}$ & & & & 0,464 & \\
\hline 7 & Öğrenmek için gereken sorumluluğu alabilirim & & & & 0,365 & \\
\hline 13 & $\begin{array}{l}\text { Veri sunumu konusunu problem-sorun çözerek } \\
\text { öğrenmek isterim }\end{array}$ & & & & & 0,591 \\
\hline 8 & Verilen konu ile ilgili bilgileri toplayabilirim & & & & & 0,574 \\
\hline 12 & $\begin{array}{l}\text { Bilgisayar dersini güncel problemlerle öğrenmek } \\
\text { isterim }\end{array}$ & & & & & 0,522 \\
\hline 11 & $\begin{array}{l}\text { Web ortamındaki öğretim yerine sınıf içinde yüz } \\
\text { yüze iletişimi tercih ederim }\end{array}$ & & & & & 0,512 \\
\hline 9 & $\begin{array}{l}\text { Problemi çözmek için başkalarıyla yarışmaktan } \\
\text { hoşlanırım }\end{array}$ & & & & & 0,482 \\
\hline 10 & $\begin{array}{l}\text { Problemi çözmeme yardımcı olabilecek ön } \\
\text { bilgilerimi kullanırım }\end{array}$ & & & & & 0,358 \\
\hline
\end{tabular}

\section{BULGULAR}

Çalışma grubuna öğrenme süreci ardından uygulanan WTPDÖ Tutum Ölçeği sonuçlarına göre sahip oldukları genel tutum düzeyleri ve tutum ölçeğinin alt boyutlarına ilişkin tutumlarının ortalamaları Çizelge 2' de verilmiştir. 
Ölçeğin toplam puanı üzerinden yorum yapmak için ölçek aralıkları belirlenirken, olası maksimum ve minimum puanlar arasındaki fark $(5-1=4)$ 6'ya (normal dağılımın \% 99,73’ü \pm 3 standart sapma arasında dağıldığı için) bölünerek, elde edilen sapma miktarı olan 0,66 değeri aracılığıyla tutumun değerlendirilmesinde kullanılan yorum ölçütüne ulaşılmıştır. Buna göre; 1,00-1,66 aralığ 1 çok düşük,1,67-2,33 aralığ1 düşük, 2,34-3,66 aralığ1 orta, 3,67-4,33 aralığı yüksek, 4,34-5,00 aralığı çok yüksek tutumu yansıtmaktadır (Meral ve ark., 2001). Tutum Ölçeği için de bu noktadan hareketle, ölçeğin uygulandığı bireylerin ortalama puanlarına bakılarak, "çok düşük" ile "çok yüksek" arasında tutum düzeyine sahiptirler yorumu yapılabilir (bakınız şekil $5)$.

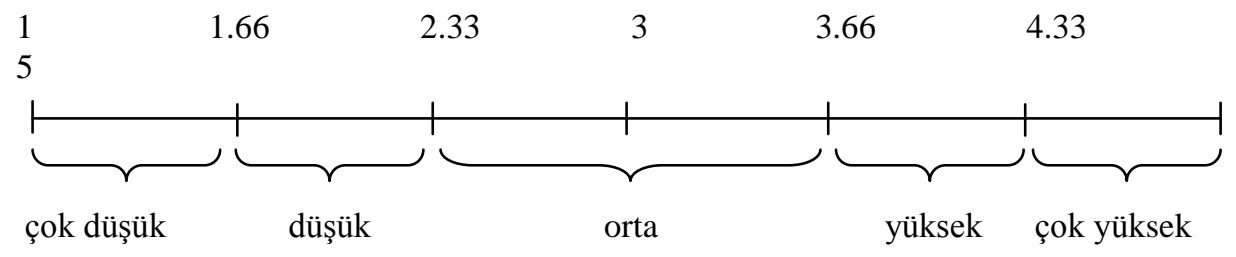

Şekil 5. Ölçek yorum ölçütü şekli

Çizelge 2. Deney grubu öğrencilerinin WTPDÖ tutum ölçeğinden aldlkları puanlara göre sahip oldukları genel tutum düzeyine ve ölçeğin alt boyutlarına ilişsin dă̆gllm

\begin{tabular}{llllllll}
\hline BOYUT & DÜZEY & PUAN & $\mathrm{f}$ & $\%$ & $\overline{\mathrm{X}}$ & $\mathrm{S}$ & $\mathrm{Sh}$ \\
& ARALIĞI & & & & & \\
\hline \multirow{3}{*}{ Bilgisayar II } & Çok Düşük & $1,00-1,66$ & 1 & 3,3 & 1,0 & - & - \\
dersine ilişkin & Düşük & $1,67-2,33$ & - & - & - & - & - \\
maddeler & Yüksek & $2,34-3,66$ & 2 & 6,7 & 2,87 & 0,176 & 0,125 \\
& Çok Yüksek & $4,67-4,33$ & 10 & 33,3 & 3,97 & 0,215 & 0,068 \\
& Toplam & & 30 & 100 & 4,250 & 0,840 & 0,153 \\
\hline \multirow{2}{*}{ İşirliğine } & Çok Düşük & $1,00-1,66$ & 1 & 3,3 & 1,2 & - & - \\
Dayalı & Düşük & $1,67-2,33$ & - & - & - & - & - \\
Öğrenmeye & Orta & $2,34-3,66$ & 5 & 16,7 & 3,04 & 0,167 & 0,074 \\
ilişkin & Yüksek & $3,67-4,33$ & 11 & 36,7 & 3,9 & 0,184 & 0,055 \\
maddeler & Çok Yüksek & $4,34-5,00$ & 13 & 43,3 & 4,65 & 0,217 & 0,060 \\
& Toplam & & 30 & 100 & 3,990 & 0,811 & 0,148 \\
\hline Web’ e Dayalı & Çok Düşük & $1,00-1,66$ & 1 & 3,3 & 1,13 & - & - \\
Öğrenmeye & Düşük & $1,67-2,33$ & - & - & - & - & - \\
İlişkin & Orta & $2,34-3,66$ & 4 & 13,3 & 3,25 & 0,322 & 0,161 \\
Maddeler & Yüksek & $3,67-4,33$ & 14 & 46,7 & 4,05 & 0,180 & 0,048 \\
\hline
\end{tabular}




\begin{tabular}{llllllll}
\hline BOYUT & DÜZEY & $\begin{array}{l}\text { PUAN } \\
\text { ARALIĞI }\end{array}$ & $\mathrm{f}$ & $\%$ & $\overline{\mathrm{X}}$ & $\mathrm{S}$ & $\mathrm{Sh}$ \\
& Çok Yüksek & $4,34-5,00$ & 11 & 36,7 & 4,72 & 0,192 & 0,057 \\
& Toplam & & 30 & 100 & 4,097 & 0,769 & 0,140 \\
\hline \multirow{3}{*}{ Kendi Kendine } & Çok Düşük & $1,00-1,66$ & - & - & - & - & - \\
Öğrenmeye & Düşük & $1,67-2,33$ & - & - & - & - & - \\
İlişkin & Orta & $2,34-3,66$ & 7 & 23,3 & 3,36 & 0,161 & 0,061 \\
Maddeler & Yüksek & $3,67-4,33$ & 16 & 53,3 & 4,04 & 0,238 & 0,057 \\
& Çok Yüksek & $4,34-5,00$ & 7 & 23,3 & 4,59 & 0,140 & 0,057 \\
\hline \multirow{5}{*}{ Problem } & Toplam & & 30 & 100 & 3,996 & 0,459 & 0,830 \\
Çözmeye & Çok Düşük & $1,00-1,66$ & - & - & - & - & - \\
İlişkin & Düşük & $1,67-2,33$ & - & - & - & - & - \\
Maddeler & Orta & $2,34-3,66$ & 4 & 13,3 & 3,29 & 0,315 & 0,157 \\
& Yüksek & $3,67-4,33$ & 18 & 60 & 3,93 & 0,163 & 0,038 \\
& Çok Yüksek & $4,34-5,00$ & 8 & 26,7 & 4,50 & 0,125 & 0,044 \\
\hline & Toplam & & 30 & 100 & 4,00 & 0,412 & 0,0753 \\
& & & & & & 9 & \\
\hline \multirow{3}{*}{ TOPLAM } & Çok Düşük & $1,00-1,66$ & - & - & - & - & - \\
& Düşük & $1,67-2,33$ & 1 & 3,3 & 1,77 & - & - \\
& Orta & $2,34-3,66$ & 4 & 13,3 & 3,36 & 0,164 & 0,082 \\
& Yüksek & $3,67-4,33$ & 15 & 50 & 4,14 & 0,168 & 0,045 \\
& Çok Yüksek & $4,34-5,00$ & 10 & 33,3 & 4,55 & 0,124 & 0,039 \\
\hline & Toplam & & 30 & 100 & 4,066 & 0,594 & 0,108 \\
\hline
\end{tabular}

(f: Frekans, \%: yüzde, $\overline{\mathrm{X}}$ : Ortalama S: Standart Sapma, Sh: Standart Hata)

Çizelge 2'ye göre uygulama süreci sonrası çalışma grubu öğrencilerinin \%3,3’ünün “düşük düzeyde tutum” sergilediği, \%13,3'ünün "orta düzeyde tutum" sergilediği, çoğunluğu teşkil eden \%50'sinin "yüksek düzeyde tutum" sergilediği, \%33,3'ünün ise "çok yüksek düzeyde tutum" sergilediği görülmektedir. Uygulama sonrasında gözlenen bu durum WTPDÖ yaklaşımına karşı öğrencilerin genel itibariyle "yüksek düzeyde olumlu tutum" sergiledikleri şeklinde değerlendirilebilir. Deney grubu öğrencilerinin WTPDÖ'ye ilişkin tutum puanlarının ortalamasının maksimum 5,00 olabileceği düşünüldüğünde, tutum puanlarının ortalamasının $\overline{\mathrm{X}}=4,07$ gibi yüksek bir değerde olduğu görülmektedir.

Ölçeğin birinci faktörüne göre, öğrencilerin \%3,3'ü bilgisayar dersine ilişkin olarak "çok düşük"; \%6,7'si "orta"; \%33,3'ü "yüksek"; çoğunluğu teşkil eden \%56,7'si ise "çok yükssek" düzeylerde tutum sergilemektedir. Bu yüzdelikler, süreçte öğrencilerin Bilgisayar II dersine karşı genel itibariyle çok yüksek ve yüksek düzeyde olumlu tutum sergilediklerini yansıtmaktadır. Çalışma grubu öğrencilerinin Bilgisayar dersine ilişkin tutum alt ölçeği puanlarının ortalaması $\overline{\mathrm{X}}=4,25$ gibi yüksek bir değerdedir. Ayrıca bu değer ölçeğin alt boyutları arasında tespit edilen en yüksek tutum değeridir. 
Ölçeğin İşbirliğine Dayalı Öğrenmeye ilişkin maddelerinin yer aldığı ikinci alt boyutuna göre öğrencilerin \%3,3'ünün "çok düşük"; \%16,7'sinin "orta"; \% 36,7'sinin "yüksek"; \%43,3'lük çoğunluluğun ise "çok yüksek" düzeyde tutum sergilediği görülmektedir. $\mathrm{Bu}$ oranlar, süreç sonunda öğrencilerin İşbirliğine Dayalı Öğrenmeye karşı genel itibariyle çok yüksek ve yüksek düzeyde olumlu tutum sergilediklerinin göstergesidir. Çalışma grubu öğrencilerinin İşbirliğine Dayalı Öğrenmeye ilişkin tutum alt ölçeği puanlarının ortalamas $1 \overline{\mathrm{X}}=3,99$ ' dur.

Ölçeğin Web'e Dayalı Öğrenmeye ilişkin üçüncü alt boyutuna öğrencilerin \%3,3'ü “çok düşük”; \%13,3'ü “orta”; \%46,7'si “yüksek”; $\% 36,7$ 'si ise "çok yüksek" düzeyde tutum sergilemektedir. Bu sonuçlardan hareketle süreç sonunda öğrencilerin Web'e Dayalı Öğrenmeye karşı genel itibariyle yüksek ve çok yüksek düzeyde olumlu tutum sergiledikleri söylenebilir. Öğrencilerin bu alt faktöre ilişkin puanlarının ortalaması $\overline{\mathrm{X}}=4,09$ ' dur.

Ölçeğin dördüncü alt boyutuna göre (Kendi Kendine Öğrenme) öğrencilerin hiç birinin düşük ve çok düşük düzeyde tutum sergilemedikleri; \%23,3'ünün "orta"; \%53,3'lük çoğunluğun "yüksek"; \%23,3'ünün de "çok yüksek" düzeyde tutum sergiledikleri görülmüsstür. $\mathrm{Bu}$ oranlara bakarak süreç sonunda öğrencilerin Kendi Kendine Öğrenmeye karşı genel itibariyle yüksek düzeyde olumlu tutum sergiledikleri söylenebilir. Öğrencilerin Kendi Kendine Öğrenmeye ilişkin tutum alt ölçeği puanlarının ortalaması $\overline{\mathrm{X}}=3,99$ olarak tespit edilmiştir.

Ölçeğin Problem Çözmeye ilişkin maddelerinin yer aldığg beşinci alt boyutuna göre öğrencilerin \%13,3'ünün "orta düzeyde tutum" sergilediği, çoğunluğu teşkil eden \%60'ının "yükssek düzeyde tutum" sergilediği, $\% 26,7$ 'sinin de "çok yüksek düzeyde tutum" sergilediği görülmektedir. Gözlenen bu yüzdelik oranlar, süreç sonunda öğrencilerin Problem Çözmeye karş1 genel itibariyle yüksek ve çok yüksek düzeyde olumlu tutum sergilediklerini yansıtmaktadır. Öğrencilerin Problem Çözmeye ilişkin tutum alt ölçeği puanlarının ortalaması $\overline{\mathrm{X}}=4,00$ 'dır.

Süreç içersinde öğrencilere "Web Tabanl Probleme Dayalı Öğrenme' nin sizce olumlu ve olumsuz yanları nedir?" şeklinde bir soru yöneltilerek, WTPDÖ stratejisi ile ilgili görüşleri yazılı olarak da alınmıştır. Öğrencilerin, "ders zevkli olduğu için zaman kavramı anlamını yitirdi, yani zaman çabuk geçiyordu"; "görevlerimi severek yapıyorum, kısacası çok memnunum"; "kendime olan güvenim arttı, kendi başıma ve arkadaşlara da danışarak neler yapabileceğimin farkına vardım"; "farklı bir ĕgitim şekli olduğu kadar, kalıcı ve etkili. Şimdilik pozitif, benden iyi not aldı"; "önceleri ders sirasinda sürekli saate bakarken bu yöntemle birlikte dersin 
çok hızlı geçtiğini düşünür olduk, artık bilgisayar dersinde sıkılmadan ders işliyoruz"; "grup arkadaşlarıyla konuları tartışırken çok güzel zaman geçiriyor ve eğleniyoruz"; "ben böyle bir çalışmadan gayet memnun kaldım"; "oturup zorla hocayı dinlemek yerine bilgisayar başında dersle ilgili konuları tartışlyoruz ve ders daha zevkli bir hale geliyor”; "ögrenirken eğleniyorum ve bir şeyler ortaya koymak beni heyecanlandırıyor" gibi ifadelerle WTPDÖ stratejisiyle işlenen derse yönelik olumlu tutum içersinde oldukları görülmüştür. Öğrencilerin vermiş oldukları cevaplardan da açıķa görülmektedir ki öğrencilerin WTPDÖ uygulamasına yönelik tutumları, tutum ölçeğinden alınan ve istatistiksel analizler sonrasında ortaya çıkan yüksek düzeydeki pozitif öğrenci tutumlarıyla paralellik göstermektedir.

\section{TARTIŞMA VE SONUÇ}

$\mathrm{Bu}$ araştırmada, WTPDÖ stratejisi ile öğrenen öğrencilerin süreç sonundaki tutumları bir grup tutum cümlesine verilen öğrenci cevaplardan çıkarsamalar yapılarak (tutum ölçeği kullanılarak) ve yazılı olarak öğrenci görüşleri alınarak belirlenmiştir. Bu iki yöntemle toplanan veriler birbiriyle paralellik göstermektedir. Uygulama süreci sonrasında, öğrencilerin sürece ilişkin genel tutumları olumlu yönde yüksek çıkmıştır. Ayrıca uygulanan ölçeğin alt faktörlerinin (Bilgisayar Dersine İlişkin Maddeler, İşbirliğine Dayalı Öğrenme, Web'e Dayalı Öğrenme, Kendi Kendine Öğrenme ve Problem Çözme) tümüne ilişkin öğrenci tutumları olumlu yönde yüksek çıkmıştır. Öğrencilerden elde edilen yazılı ifadelerde büyük oranda WTPDÖ sürecinin olumsuz yönünün olmadığını belirttikleri görülmüştür. Bu ve buna benzer ifadelerden ve ölçekten elde edilen tutum puanları ortalamalarından hareketle bireysel performansa ve grup çalışmasına olumlu etkileri olacağ 1 düşünülen öğrenci tutumlarının yüksek olduğu sonucuna ulaşılabilir. Deveci (2002) ve Yaman (2003) yaptıkları PDÖ çalışması sonucunda öğrencilerin derse karş1 yüksek tutum sergilediklerini; Reznich ve Werner (2001) de ögrencilerin web tabanlı teknolojileri kullanarak öğrenmeye ilişkin olumlu görüşleri olduğunu belirtmişlerdir. Alan yazında yer alan bu sonuçlar, yürütülen araştırmanın sonuçlarıyla paralellik göstermektedir. Araştırma sonucu elde edilen, öğrenci tutumlarıyla ilgili sonuçların olumlu yönde yüksek olmasından dolayı, WTPDÖ'nün Bilgisayar dersinde ve uygun olan diğer derslerde kullanılması önerilebilir.

Öğrencilerden elde edilen nitel verilerden yararlanarak, bazı öğrencilerin alışkın olmadıkları yeni bir yöntemle ve web tabanlı ortamda ders işlemenin ilk başlarda kendilerini zorladığını, fakat zamanla bu duruma alıştıklarını ve dersin zevkli ve verimli bir hal aldığını belirttikleri 
saptanmıştır. Bu durum, Oliver ve McLoughlin (2000) de belirttiği gibi WTPDÖ'nün kullanışlı olma durumunu destekler niteliktedir.

Çizelge 2 incelendiğinde, tutum ölçeğinin Bilgisayar dersine ilişkin maddeler, İşbirliğine Dayalı Öğrenmeye ilişkin maddeler ve Web' e Dayalı Öğrenmeye İlişkin Maddeler alt boyutlarına ilişkin bir öğrencinin çok düşük tutum sergilediği görülür. Ölçeğin Kendi Kendine Öğrenmeye İlişkin Maddeler ve Problem Çözmeye İlişkin Maddeler alt boyutlarında ise düşük düzeyde tutum söz konusu değildir. Çok düşük tutum sergilenen alt boyutların öğrencinin diğer öğrencilerle beraber gerçekleştirmesi gereken bazı faaliyetlerle ilgili maddeleri barındırdığı görülmüştür. Elde edilen bu verilerden, genel itibariyle ögrencilerin olumlu yönde pozitif tutum sergilemelerine karşın bazı öğrencilerin tutumlarının pek de olumlu olmayabileceği görülmektedir. Öğrencilerden elde edilen nitel veriler incelendiğinde, öğrencilerin bazılarının grup üyeleriyle düşünce paylaşımı sırasında sorun yaşadıklarını, grup üyelerine düşüncelerini kabul ettiremediklerini, sanal ortamda kurulan iletişimin yüz yüze iletişimin yerini tutamadığını belirttikleri saptanmıştır. $\mathrm{Bu}$ bulgulardan hareketle bazı öğrencilerin diğer grup üyeleriyle iletişimin önemli olduğu bu yeni yaklaşıma adapte olamayabilecekleri sonucuna ulaşılabilir. Araştırmacının yapmış olduğu bireysel gözlemler sonucunda da, WTPDÖ sürecinde grup içi iletişimin öğrenme sürecinde önemli bir yer teşkil ettiği gözlemlenmiştir. Bundan hareketle yeni yapılacak çalışmalarda grup içi iletişimin etkililiği ile ilgili çalışmaların yapılması önerilebilir.

$\mathrm{Bu}$ araştırma lisans eğitimi alan yetişkin bireylerle meslek yaşamlarında karşılaşabilecekleri bir durum konu alınarak yürütülmüştür. Yeni yapılacak araştırmaların WTPDÖ stratejisi ile farklı öğrenim düzeylerinde ve uzun bir zaman dilimine yayılarak yürütülmesi önerilebilir.

Bu araştırmada WTPDÖ' ye ilişkin öğrenci tutumları Üç Öğeli Tutum Modelinin (Tavşancıl, 2002) Tutumun Duyusssal Öğesi dikkate alınarak belirlenmiştir. Öğrencilerin kendi ifadelerinden oluşan bir ölçek (bir grup tutum cümlesine verilen cevaplardan çıkarsamalar) aracılığı ile tutumlar ölçülmüştür. Fakat tutumları ölçmek için farklı yöntemler de mevcuttur. Bu yöntemlerden, uzman değerlendirmesi aracılı̆̆ıyla davranışlardan yapılan çıkarsamalar yolu ile öğrenci tutumlarının belirlenmesi yoluyla tutumun davranışsal öğesi de tespit edilebilir. Elde edilen verilerin ölçekten alınan verilerle kıyaslamalı ortaya konması daha güvenilir sonuçlar verebilecektir. Ayrıca bu şekilde tutum gelişiminin hangi aşamasında olunduğuna ilişkin bilgiler de elde edilmiş olacaktır. Bu doğrultuda yeni yapılacak çalışmalarda imkanlar ölçüsünde her iki yöntemin eşzamanlı kullanımı önerilebilir. 


\section{KAYNAKLAR}

Alper, A.Y. (2003). Web ortaml probleme dayal öğrenmede bilişsel esneklik düzeyinin öğrenci başarısı ve tutumları üzerindeki etkisi. Yayınlanmamış doktora tezi. Ankara Üniversitesi Eğitim Bilimleri Enstitüsü, Ankara.

Barrows, H.S. (1985). How to design a problem-based curriculum for the precilinical years. New York: Springer Publishing.

Büyüköztürk, Ş. (2002). Faktör analizi: temel kavramlar ve ölçek geliştirmede kullanımı. Eğitim Yönetimi Dergisi, Güz, 470-473.

Catney, M.C. ve Currie J.D. (1999). Implementing problem based learning with www support in an introductory pharmaceutical care course. American Journal of Pharmaceutical Education, 63, (1), 96-105.

Çıkrıkçı, N. (1991). Tutumların ölçülmesi. Ankara Üniversitesi Eğitim Bilimleri Fakültesi Dergisi, 24, (1), 241-250.

Deryakulu, D. (1995). Öğretme-Öğrenme Süreçleri, C.Alkan (Ed.) Öğretim teknolojilerine giriş “disiplin süreç ürün”.(ss.44-78). Ankara: Önder Matbaas1.

Deveci, H. (2002). Sosyal bilgiler dersinde probleme dayalı ögrenmenin ögrencilerin derse ilişkin tutumlarına, akademik başarılarına ve hatırlama düzeylerine etkisi. Yayınlanmamış yüksek lisans tezi. Anadolu Üniversitesi Eğitim Bilimleri Enstitüsü, Eskişehir.

Duffy, T.M. ve Jonassen, D.H. (1992). Constructivism and the technology of Instruction: A conversation. New Jersey: Lawrence Erlbaum Associates.

Heinrics, K. I. (2002). Problem-based learning in entry-level athletic training professional-education programs: A model for developing critical thinking and decision-making skills. Journal of Athletic Training, 37, (4), 189-198.

Helvacı, M.A. (2008). Okul yöneticilerinin teknolojiye karşı tutumlarının incelenmesi (uşak ili örneği). Ankara Üniversitesi Eğitim Bilimleri Fakültesi Dergisi,41,(1), 115-133.

Ifamuyiyiwa, S.A. ve Akinsola, M.K. (2008). Improving senior secondary school students' attitude towards mathematics through self and cooperative-instructional strategies. International journal of mathematical education in science and technology, 39, (5), 569-585.

Köklü,N. (1995). Tutumların ölçülmesi ve likert tipi ölçeklerde kullanılan alternatif seçenekler. Ankara Üniversitesi Eğitim Bilimleri Fakültesi Dergisi, 28(2), 81-94. 
Meral, M., Cambaz, H. ve Zereyak, E. (2001). Öğretmenlerin bilgisayara karş1 tutumları ve bilgisayar kaygısı. Bilişim Teknolojileri Işığında Eğitim Konferanst ve Sergisi, 3-5 Mayıs 2001, Ankara.

Oliver, R. ve McLoughlin, C. (2000). Using web and problem-based learning environments to support the development of key skills. 22.08.2008' de, Web üzerinde: http://www.ascilite.org.au/conferences/brisbane99/papers/olivermcloug hlin.pdf adresinden alınmıştır.

Oppenheim, A.N. (1966). Questionnaire Design and Attitude Measurement. New York: Basic Books Publishers.

Özdemir, S. (2005). Web ortaminda bireysel ve işbirlikli problem temelli ögrenmenin eleştirel düşünme becerisi, akademik başarl ve internet kullanımına yönelik tutuma etkileri, Yayınlanmamış Doktora Tezi, Gazi Üniversitesi Eğitim Bilimleri Enstitüsü, Ankara.

Reznich, C.B. ve Werner, E. (2001). Integrating technology in to PBL small groups in a medical education setting. ERIC:ED452 786.

Stromso, H. I., Grottumpt, P. ve Lycke, K.H. (2007). Content and proccess in problem based learning: A comparision of computer mediated and face to face communication. Journal of computer assisted learning, 112.

Şimşek, N. (2004). Yapılandırmacı öğrenme ve öğretime eleştirel bir yaklaşım. Eğitim Bilmleri ve Uygulama. 3, (5), 114-139.

Tavşancıl, E. (2002). Tutumların ölçülmesi ve SPSS ile veri analizi. Ankara: Nobel Yayınevi.

Tekindal, S. (2002). Duyuşsal özelliklerin ölçülmesi için araç oluşturma. Kocaeli: Kocaeli Kitap Kulübü Yayınları.

Wood, D. F. (2003). ABC of learning and teaching in medicine: Problem based learning. Clinical Review, 326.

Yaman, S. (2003). Fen bilgisi eğitiminde probleme dayalı öğrenmenin ögrenme ürünlerine etkisi. Yayınlanmamış doktora tezi. Gazi Üniversitesi Eğitim Bilimleri Enstitüsü, Ankara.

Yang, S.P. (2001). Problem-based learning on the world wide web in an undergraduate kinesiology class: an integrative approach to education, Unpublished PhD Thesis. University of New Brunswick, New Brunswick, Canada.

Yurdakul, B. (2005). Yapılandırmacılık. Ö.Demirel, (Ed.). Eğitimde Yeni Yönelimler (2. Baskl). (ss.38-66). Ankara: Pegem A Yayıncılık. 